\title{
Ritual and Ritual Obligations: Perspectives on Normativity from Classical China
}

\author{
Michael Puett ${ }^{1}$
}

Published online: 19 September 2015

(C) The Author(s) 2015. This article is published with open access at Springerlink.com

The goal of this paper is to explore some of the theories that arose in classical China concerning the ways in which normativity could be construed in ritual terms. I focus particular attention on the theories that were developed in portions of the Book of Rites (Liji), which would become one of the most influential bodies of ritual theory throughout East Asia. I will argue that some of these theories deserve to be incorporated into our contemporary philosophical understandings of normativity.

To make this argument, I will be turning to some rather - given my ultimate goals in this paper - counterintuitive material, including early Chinese discussions of mourning rituals. But I will try to argue that this material has something to offer contemporary discussions.

\section{Rituals and Norms}

Let me begin by mentioning one of the common criticisms made against the argument that we should take theorists of ritual seriously when discussing norms. Perhaps one of the reasons we often denigrate the significance of rituals is that we think rituals essentially function to socialize us into a way of thinking and acting. In other words, rituals tell us what to do. So, if the norms embedded within a given ritual are good, then the ritual would perhaps be acceptable. But what if the norms are not, from our point of view, acceptable? Following them would then entail submitting ourselves to "traditional" values, as opposed to having norms that could at least potentially be rationally adjudicated and altered.

It is, of course, entirely possible to have ritual traditions that become rigidified and function in a top-down way to instill values on a population. But thinking that

Michael Puett

puett@fas.harvard.edu

1 Harvard University, Cambridge, USA 
this is the only way rituals can work is very limiting. It may therefore be worthwhile to look at indigenous theories of ritual from a so-called traditional society - in this case, classical China - to see how these issues are conceptualized. Intriguingly, they offer not only a suggestive way to think about rituals, but also a suggestive way to think about norms in general.

\section{The Work of Mourning Rites}

The chapters of the Book of Rites (Liji 禮記) were written over the course of the fourth, third, and second centuries BCE, and were compiled into a single text by the first century BCE. The text was thereafter defined as one of the "Five Classics," and became part of the standard educational curriculum throughout East Asia for much of the subsequent two millennia.

One of the key ideas underlying these chapters is the notion that ritual should transform our emotional dispositions. ${ }^{1}$ In any situation, humans have tendencies to respond to situations in particular ways, and the goal of rituals is to shift these responses. For example, when someone passes away, we tend to be overtaken with grief and even anger. Mourning rituals force a change. ${ }^{2}$

The "Tan gong" chapter of the Book of Rites takes the reader through the early stages of the rituals immediately following a death. The chapter argues that the ritual world of mourning helps to modulate one's grief over a death and to alter those emotions such that they are shifted into a sense of remembrance of that from which one came:

The rites of mourning are the extreme [expression] of grief and sadness. In modulating grief, one [learns to] accord with the changes [of life and death]. This is how the refined person remembers from where he came. ${ }^{3}$

To ensure this transition, the practitioner is taken through a series of steps in the ritual.

At first, the mourner expresses his grief toward the deceased:

Bowing and hitting one's head on the floor is the extreme pain of grief and sadness. Hitting one's head on the floor is the depth of the pain. ${ }^{4}$

\footnotetext{
${ }^{1}$ For a fuller discussion of ritual theory in the Book of Rites, see Michael Puett, "Ritual Disjunctions: Ghosts, Philosophy, and Anthropology," in Veena Das, Michael Jackson, Arthur Kleinman, and Bhrigupati Singh, eds., The Ground Between: Anthropologists Engage Philosophy (Durham: Duke University Press, 2014), pp. 218-233; and Michael Puett, "The Haunted World of Humanity: Ritual Theory from Early China," in J. Michelle Molina and Donald K. Swearer, with Susan Lloyd McGarry, eds., Rethinking the Human (Cambridge: Center for the Study of World Religions, 2010), pp. 95-111.

${ }^{2}$ For a fuller discussion of mourning rituals in the Book of Rites, see Michael Puett, "Combining the Ghosts and Spirits, Centering the Realm: Mortuary Ritual and Political Organization in the Ritual Compendia of Early China," in John Lagerwey and Marc Kalinowski, eds., Early Chinese Religion: Shang Through Han (1250 BC-220 AD) (Leiden: Brill, 2009), pp. 695-720.

3 Liji, "Tan gong," Chinese University of Hong Kong, Institute of Chinese Studies, Ancient Chinese Text Concordance Series (hereafter cited as ICS), 23/4.15/11. My translations here and throughout have been aided greatly by those of James Legge, Li Chi: Book of Rites (Oxford: Oxford University Press, 1885).

4 Liji, "Tan gong," ICS, 23/4.15/12-13.
} 
The grief is played out ritually by bowing to the deceased and hitting one's head on the floor.

After the deceased is interred in a tomb, the mourner returns home and wails. This is the point of most extreme grief, as the deceased has now left the home forever. The mourner is consoled by the rest of the mourning party upon returning:

Consoling when [the descendant] returns [from the tomb] wailing is because this is the extremity of grief. He returns and there is no one there; he has lost [the deceased]. Therefore it is the most intense. ${ }^{5}$

The wailing upon the return is part of the ritual. The wailing at this moment is defined as being at its strongest.

And it then has to stop. Following the internment, sacrifices to the deceased are begun. A transition must now be made from mourning the deceased to sacrificing to the deceased as an ancestor. All wailing must cease at this point:

The end of wailing is called "completing the event." On this day, auspicious sacrifices replace sacrifices of mourning. The next day, [the tablet] is enshrined with the grandfather. ${ }^{6}$

An ancestral tablet is made for the deceased, and the tablet is enshrined in the ancestral temple. The spirit of the deceased will now be called to the tablet. The enshrining of the tablet must be done quickly - the living cannot bear the idea of the spirit not having a place to return, now that the corpse has been buried in a tomb.

Changing to auspicious sacrifices, and on the succeeding day to the enshrining of the tablet, must necessarily occur very close to this day. He [the survivor] cannot bear one day without a place [for the spirit] to return. ${ }^{7}$

The transition must now be complete from the mourning period to the subsequent period in which the deceased will be worshipped as an ancestor. The crying must end, and the name of the deceased must no longer be mentioned. He is now an ancestor, and will be worshipped as such, with an impersonator playing the role of the ancestor in accepting the sacrifices.

One performs the sacrifice of repose and sets up the impersonator. There is a bench and a mat. One brings to an end the crying and avoids [the name of the deceased]. The services for him as living are stopped and the services for the ghost begin. ${ }^{8}$

At this point, the goal is to stop grieving and start developing properly filial dispositions toward the deceased as an ancestor.

Elsewhere in the Book of Rites the distinction is made clearly:

\footnotetext{
5 Liji, "Tan gong," ICS, 23/4.15/20.

6 Liji, "Tan gong," ICS, 23/4.15/21-24.

7 Liji, "Tan gong," ICS, 23/4.15/24-25.

8 Liji, "Tan gong," ICS, 28/4.52/6.
} 
In sacrificing, one is called "filial son" and "filial grandson." In mourning, one was called "grieving son" and "grieving grandson."

The arc of the ritual thus takes the living from one of mourning for the deceased to one of sacrificing to the deceased in the form of an ancestor. If the ritual is effective, it means that the dispositions have been altered in a direction deemed better for the living.

This shift in the ritual from grieving for the deceased loved one to treating him as an ancestor itself operates entirely in the ritual space. Needless to say, there is no such clean shift in our emotional dispositions. After the ritual ending of the crying and the ritual beginning of ancestral sacrifices, one will of course continue to cry outside of the ritual space. But, if the rituals are effective, they create a space of practice within which different dispositions are being developed - dispositions that will be in tension with our sense of loss from the death of a loved one.

Once the transformation to ancestral sacrifices occurs in the ritual, a bifurcation develops for the living. Within the ritual space, the practitioner is being trained to think of the deceased as an ancestor and to repeatedly inculcate within himself the sensibility of remembering from where he came. But this is not a simple norm that will guide his life. Indeed, the reason the ritual has to be constantly repeated is to reinculcate these dispositions over and over, as they are hardly the values that are guiding his behavior outside the ritual space.

\section{Understanding Ritual}

This discussion of archaic rituals from early China may seem - at best - interesting as an exercise in historical archaeology. But I would like to argue that there is much here that is good to think concerning norms in general.

So how should we interpret these rituals?

One way - and perhaps the most common way in contemporary theory - would be to assume that ritual serves to inculcate a worldview that the practitioner is being called upon to accept. From such a perspective, the goal of the analyst would be to explore the views that are embedded in the ritual and try to work out the larger worldview in which such ideas would make sense.

In the case at hand, the goal of the ritual would be read as trying to inculcate a proper reverence for the deceased as an ancestor. This would then be analyzed in terms of a larger worldview in which humans would be taught to see themselves as following the dictates of ancestral powers.

This is, in fact, the most common way these early Chinese ancestral rituals have been interpreted by modern scholars. But, as I have argued elsewhere, it is a misreading. ${ }^{10}$ The Book of Rites presents ancestors as a product of ritual, and they

\footnotetext{
9 Liji, “Za ji,” ICS, 107/20.12/6.

10 Puett, "The Offering of Food and the Creation of Order: The Practice of Sacrifice in Early China," in Roel Sterckx, ed., Of Tripod and Palate: Food, Politics, and Religion in Traditional China (New York: Palgrave MacMillan, 2005), pp. 75-95.
} 
are revered as such only within the ritual space. Outside the ritual space, they are regarded as ghosts, and potentially very dangerous ghosts.

In other words, one should not try to make sense of rituals by working out the larger worldview that a ritual is supposedly trying to inculcate. On the contrary, rituals often work because they are counter-intuitive to our usual ways of thinking, acting, and responding. And it is precisely the tension between rituals and our lived reality that render them effective.

\section{The “As If” World of Ritual}

For our concerns, one of the more significant statements in the early Chinese tradition concerning ritual appears in the Analects of Confucius:

'Sacrifice as if present,' means: sacrifice to the spirits as if the spirits were present. The master said, "If I do not participate in the sacrifice, it is as if I did not sacrifice.',11

The "as if" world of the ritual involves the presence of both the human practitioner and the spirits. Within this "as if" world, the practitioner and the spirits are in close proximity, and the practitioner works to forge a proper relationship between the descendant and ancestor. But whether the spirits are actually present or not is irrelevant. The ritual rather serves as a space within which one acts "as if" they are present.

Moreover, as is clear from other statements, this ritual space is clearly demarcated from the non-ritual world. It may not matter if the spirits are present or not in the ritual space. But one actually does not want them to be present, or at least not closely so, outside the ritual space. As the Analects states elsewhere:

Fan Chi asked about knowledge. The master said, "To work on behalf of what is proper for the people, to be reverent to the ghosts and spirits and yet keep them at a distance, this can be called knowledge."12

One wants the presence (whether actual or not) of the spirits in the "as if" world of the ritual space; outside it, one wants the spirits kept at a distance.

Within the ritual space, one develops the proper dispositions one should have in a relationship between an ancestor and a descendant. This helps to re-inculcate into oneself the sensibility of being a proper descendant. Outside the ritual space, one is guided by separate dispositions.

The "as if" world of ritual is clearly marked off as such, demarcated from the world of lived reality outside the ritual space. It is not a world we could live in. But, perhaps more importantly, we would not want to live in the "as if" world, even if this were possible. The "as if" world is not a simple repository of norms that could guide our behavior in the world of our lived reality. The power of the "as if" on the

\footnotetext{
11 Lunyu, 3/12.

12 Lunyu, 6/22.
} 
contrary resides in the productive tension that it generates with the world of our lived experience.

Several colleagues and I have argued that early Chinese understandings of ritual should be taken seriously from a theoretical perspective as well. In these understandings, ritual serves to create an "as if" space - what we call a subjunctive space - in which dispositions can be trained. ${ }^{13}$ What is of particular significance is that, in such understandings, normative values are located not in the "as if" space itself but rather in the disjunction between the "as if" space and our experiences outside of the ritual space:

These arguments imply that ritual always operates in a world that is fragmented and fractured. Moreover, the subjunctive world created by ritual is always doomed ultimately to fail - the ordered world of flawless repetition can never fully replace the broken world of experience. This is why the tension between the two is inherent and, ultimately, unbridgeable. Indeed, this tension is the driving force behind the performance of ritual: the endless work of ritual is necessary precisely because the ordered world of ritual is inevitably only temporary.... If the world is always fractured, and if ritual always operates in tension with such a world, then we need to think of ritual in terms of such an endlessly doomed dynamic. Ritual should be seen as operating in, to again quote Robert Orsi, "the register of the tragic." Although the claims of ritual may be of an ordered, flawless system, the workings of ritual are always in the realm of the limited and the ultimately doomed. ${ }^{14}$

\section{Where are the Norms?}

Let us think through the larger implications of the position under discussion here. We often tend to think of norms in the form of rules to guide our behavior. And having such norms embedded in rituals would appear to be extremely limiting. To begin with, we frequently assume that rituals provide a type of normative order to which we should try to approximate our behavior. If this is really the way rituals function, then they would simply be telling us what to do. Moreover, as mentioned above, having such rules embedded in rituals would seem to limit the potentials for altering those norms: if the rules embedded in rituals are based upon traditional values, and if rituals serve to inculcate those traditional values within ourselves, then they would be extremely difficult to alter.

But the vision being developed by the ritual theorists from classical China opens up a different way to think about rituals and, by implication, a different way to think

\footnotetext{
13 Adam Seligman, Robert Weller, Michael Puett, and Bennett Simon, Ritual and its Consequences: An Essay on the Limits of Sincerity (Oxford: Oxford University Press, 2008). For a superb analysis of "as if" from a larger philosophical perspective, see Hans Vaihinger, The Philosophy of 'As if': A System of the Theoretical, Practical and Religious Fictions of Mankind, translated by C. K. Ogden, second edition (New York: Harcourt, Brace and Company, 1935).

14 Adam Seligman, Robert Weller, Michael Puett, and Bennett Simon, Ritual and its Consequences: An Essay on the Limits of Sincerity (Oxford: Oxford University Press, 2008), p. 30.
} 
about norms. Rituals do not, in these theories, teach us what to do; they rather, to refer back to the statement quoted above, operate in the realm of the tragic: they operate in the very disjunction between the "as if" world of ritual and our lived reality. ${ }^{15}$

The ritual of ancestor worship is not a norm in the sense of something that we blindly follow: the ritual is not inculcating a belief in ancestors. Instead, it works because the relationships that are being built in the ritual space are in tension with the relationships that exist outside the ritual space.

\section{What are the Norms?}

These ritual theories assume a particular vision of the self. As humans, we tend to fall into sets of patterned responses to the world. The goal of rituals - of "as if" spaces - is to break us out of these patterns. However, it is not the case that these asif spaces are therefore the locus of normativity - in other words, that ritual is functioning to socialize us into the norms embodied in the ritual. The rituals are not telling us what to do; our patterned set of responses is rather guiding our everyday lives. The point of ritual is to break us out of these patterns.

According to the Analects, the goal of this work - of working through the disjunctions created between ritual and the world of our lived experience - is to create humaneness (ren 仁). Humaneness is notoriously difficult to explicate precisely, because it is a sensibility - a sensibility of how to act in ways that will help those around one. In one passage of the Analects, Confucius is quoted as defining humaneness, vaguely but tellingly, as "Caring for others." ${ }^{16}$ And, of course, what this means in any particular situation will vary dramatically. But the reason we need to work through rituals to attain this sensibility is because, according to this way of thinking, we on the contrary fall into patterns in our responses to the world, and thus cease to be able to sense how to act humanely. The work of ritual - of breaking these patterns by entering "as if" spaces - is thus in a sense a training exercise in which we are training ourselves to respond to situations better.

In the case of the mourning rituals, the goal is not to inculcate a particular view of ancestors. The goal of the rituals is to break us from our tendency to fall into dangerous patterns at the death of a loved one and to help us channel these dispositions more productively. Out of the disjunction between these two will hopefully come a more refined way of responding to the world.

Ritual norms, in other words, are not rules that we simply follow. Rituals rather work because they create sets of patterned responses that stand in tension with the patterned responses we have in our lived reality. It is, in short, the disconnect between rituals and lived reality that makes rituals so effective.

\footnotetext{
15 Michael Puett, "Ritual Disjunctions: Ghosts, Philosophy, and Anthropology," in Das et al., eds., op. cit., pp. 218-23. See also "Critical Approaches to Religion in China," Critical Research on Religion 1 (2013): 95-101.

${ }^{16}$ Lunyu, 12.22 .
} 
It is not the case, then, that the norms are to be found in the rituals, with the rituals forming a kind of normative set of rules that should guide our behavior. Rituals on the contrary operate to force us out of our patterned responses to the world. But the patterns that rituals offer are hardly ones that we would always be following either. The guiding norm is rather a sensibility of responding to situations well - a sensibility we attain by working through the disjunctions between our common lived behavior and the as-if worlds of rituals. Rituals are not the repository of norms but rather the ever-altering means to achieve norms.

\section{Conclusion}

The understandings of ritual that we have been exploring open up a possible way of thinking about norms. According to the ritual theorists under discussion here, norms are located not in a series of rules that should be followed. Norms are rather to be found in the sensibilities that are developed over time, and the way that such norms are developed is through the tension between rituals and our lived reality. We are constantly creating pockets of "as if" realities, and the disjunction between these pockets and the patterns that we fall into in our lived reality is the basis for us to transform ourselves. But what we are seeking is not to become more like the person we are in these as-if spaces. The goal is rather to learn to respond to situations well an ability we gain through the endless work of training ourselves through ritual activity.

From this perspective, rituals are best thought of as patterned set of responses operating in tension with the patterned set of responses that usually govern our lives. And norms should rather be thought of as more generalized (and often quite illdefined) concepts such as caring. Rituals are then, in a sense, a way of training ourselves to break from those patterns that usually prevent us from being caring toward others.

Taking these theories from classical China seriously allows us to view rituals, and, ultimately, norms in a different way. If rituals are thought of not as a repository of norms into which we are being inculcated but rather as a series of "as if" worlds that stand in tension with our lived reality, then they become the means through which we train ourselves to become more able to care for those around us.

Open Access This article is distributed under the terms of the Creative Commons Attribution 4.0 International License (http://creativecommons.org/licenses/by/4.0/), which permits unrestricted use, distribution, and reproduction in any medium, provided you give appropriate credit to the original author(s) and the source, provide a link to the Creative Commons license, and indicate if changes were made. 